\title{
INFLUENCE OF SOIL FERTILIZATION ON CONCENTRATION OF MICROELEMENTS IN SOIL SOLUTION OF SANDY SOIL
}

\author{
Beata Rutkowska, Wiesław Szulc, Jan Labętowicz \\ Chair of Soil Environment Sciences \\ Warsaw University of Life Sciences (SGGW)
}

\begin{abstract}
The study was carried out to asses the influence of soil mineral fertilization, manure application and soil liming on changes in the concentration of microelements $(\mathrm{B}, \mathrm{Cu}, \mathrm{Fe}$, $\mathrm{Mn}$ and $\mathrm{Zn}$ ) in soil solution. The tests were performed on samples of sandy soil collected from long-term fertilization experiments being conducted on lessive soil of the granulometric structure of clayish sand. Soil solution was prepared with the suction method. The concentration of microelements in soil solution was determined by means of the ICP method. The results showed an increase in $\mathrm{Fe}, \mathrm{Mn}, \mathrm{Zn}$ and $\mathrm{Cu}$ and a decrease in $\mathrm{B}$ and Mo in soil solution when soil was fertilized with nitrogen. The concentration of microelements in soil solution was not significantly influenced when soil was fertilized with phosphorous and potassium. Liming had a significant effect on a decrease in the concentration of $\mathrm{Fe}$, $\mathrm{Mn}, \mathrm{Zn}$ and $\mathrm{Cu}$ and an increase in $\mathrm{B}$ and $\mathrm{Mo}$ in soil solution. Soil application of manure significantly increased the concentration of microelements in soil solution.
\end{abstract}

Key words: microelements, soil solution, mineral fertilization, manure, liming.

\section{WPEYW NAWOŻENIA NA STĘŻENIE MIKROELEMENTÓW W ROZTWORZE GLEBOWYM GLEBY LEKKIEJ}

Abstrakt

Celem pracy była ocena wpływu nawożenia mineralnego oraz stosowania obornika i wapnowania na zmiany stężenia mikroelementów (B, Cu, Fe, Mn i $\mathrm{Zn}$ ) w roztworze glebowym gleby lekkiej. Próbki glebowe pobrano $\mathrm{z}$ trwałego doświadczenia nawozowego prowadzonego na glebie płowej o składzie granulometrycznym piasku gliniastego lekkiego. Roz-

dr hab. Beata Rutkowska, Chair of Soil Environment Sciences, Warsaw University of Life Sciences, Nowoursynowska 159 Str., 02-776 Warsaw, Poland 
twór glebowy pozyskiwano metodą podciśnieniowa. W roztworze glebowym mikroelementy oznaczono metodą ICP. Stwierdzono, że w warunkach nawożenia azotem obserwuje się zwiększenie stężenia żelaza, manganu, cynku i miedzi oraz zmniejszenie stężenia boru i molibdenu w roztworze glebowym. Nawożenie fosforem i potasem nie wpływa istotnie na stężenie mikroelementów w roztworze glebowym.

Wapnowanie przyczynia się do zmniejszenia stężenia żelaza, manganu, miedzi i cynku oraz zwiększenia stężenia boru i molibdenu w roztworze glebowym, a pod wpływem stosowania obornika obserwuje się istotne zwiększenie stężenia mikroelementów w roztworze glebowym.

Słowa kluczowe: roztwór glebowy, nawożenie mineralne, obornik, wapnowanie, mikroelementy.

\section{INTRODUCTION}

Soil solution is the environment where most important chemical reactions take place. Being a soil liquid phase, it controls transfer of dissolved components throughout the whole soil profile. Soil solution is involved in the transport of pollutants in soil and plays a significant role in the transport of elements in ecosystems. However, the most important function of soil solution is its involvement in plant feeding, as it constitutes the main source of water and food elements for plants (CAMPBELl et al. 1989, Wolt 1994, ŁABÉTOWICZ 1995, PoręBSKA 2003). For many years now, the concentration of elements in soil solution has been treated as the indicator of soil fertility (HoAgLAND et al. 1920). Analyses of the chemical content of soil solution provide important data on the influence of agricultural practices, such as mineral fertilization (CURTIN, SMILlie 1983, ŁaBĘTOWICZ 1995, Simard et al. 1988, SMal 1999) on the condition of soil environment.

The aim of this study has been to assess the influence of mineral fertilization, application of manure and soil liming on changes in the concentration of microelements $(\mathrm{B}, \mathrm{Cu}, \mathrm{Fe}, \mathrm{Mn}$ and $\mathrm{Zn})$ in soil solution of sandy soil.

\section{MATERIAL AND METHODS}

Assessments were carried out on soil samples collected from long-term fertilization experimental plots established in 1960 on lessive soil possessing granulometric features of clayish sand (classified by FAO as Albic Luvisols). The experiments encompass 16 objects being randomly fertilized by main components $\mathrm{N}, \mathrm{P}, \mathrm{K}, \mathrm{Ca}$ with or without application of manure. Thus, the whole experiment included 32 fertilized objects with 4 replications. Potatoes, spring barley, rape (or mustard plant) and rye are cultivated in fourfield crop rotation. Mineral fertilization was carried out at the following average rate $(\mathrm{kg})$ per hectare: $140 \mathrm{~N}$ (ammonium nitrate), $50 \mathrm{P}$ (triple 
superphosphate), $140 \mathrm{~K}$ (high percentage potassium salt). Liming (calcium carbonate) was applied every 4 years at a rate $1.14 \mathrm{Mg}$ Ca per ha. Manure was applied at a rate 30 and $20 \mathrm{Mg}$ per ha at each rotation of potatoes and rape (or mustard plant), respectively. Fertilization with microelements was not applied. Soil samples were collected from soil plough layer, then dried at $55^{\circ} \mathrm{C}$. Soil solution was obtained with the suction method. The microelements: B, Cu, Fe, Mn, Mo and $\mathrm{Zn}$ were assessed with the ICP method. Evaluation of the influence of fertilization elements (N, P, K) applied when liming or manure were used was carried based on analyses of the main effects on the concentration of observed elements in soil solution as well as their interactions (expressed in \%). The average value calculated from all combinations where a given fertilizer was not applied was treated as the zero level $(0 \%)$.

\section{RESULTS AND DISCUSSION}

The results of the examination of the effects produced by the tested fertilizer compounds' on the concentration of microelements in soil solution showed a significant increase in the concentration of $\mathrm{Fe}, \mathrm{Mn}, \mathrm{Cu}$ and $\mathrm{Zn}$ in soil solution when soil was fertilized with nitrogen (Figure 1). The results on the effects of nitrogen fertilization on microelement uptake reported by other authors indicate that application of nitrogen fertilizers, and mainly ammonium nitrate, results in a decrease of soil reaction, which is associated with an increase of the concentration of microelements uptaken in the form of cations in soil solution (SANDERs 1982, 1983, Curtin, Smillie 1983, Simard et al. 1988, Smal 1999, AdAms et al. 2001). An increase of solubility and mobility of many trace elements has been shown together with a decrease of $\mathrm{pH}$ by several authors (GEBSKI 1998, GoRLACH, Gambuś 2000, BADORA 2002). MCBRIDE and BLASIAK (1979) showed that solubility of zinc decreased 30 -fold per one unit of an increase of $\mathrm{pH}$ in a range of $\mathrm{pH} 5.0-\mathrm{pH}$ 7.0.

On the other hand, the concentration of boron and molybdenum in soil solution decreased with nitrogen fertilization (Figure 1). Under the conditions of lowered $\mathrm{pH}$ of sandy soil, the physicochemical adsorption of boron is reduced on particles of the solid soil layer, which enlarges losses of this element as a result of leaching down through the soil profile. As GoldBera and Glaubig (1986) reported, the maximum boron adsorption occurs at $\mathrm{pH}=8.0-10.0$, both on crystalline and amorphic oxides of iron and aluminum as well as on loamy minerals. The possibility of leaching of boron in the form of borane ions has not been called in question for a long time (ŚWIECICKI 1964).

Application of phosphorous fertilizers did not significantly influence the concentration of $\mathrm{Fe}, \mathrm{Mn}, \mathrm{Zn}$ and $\mathrm{Cu}$ in soil solution (Figure 1). The results 

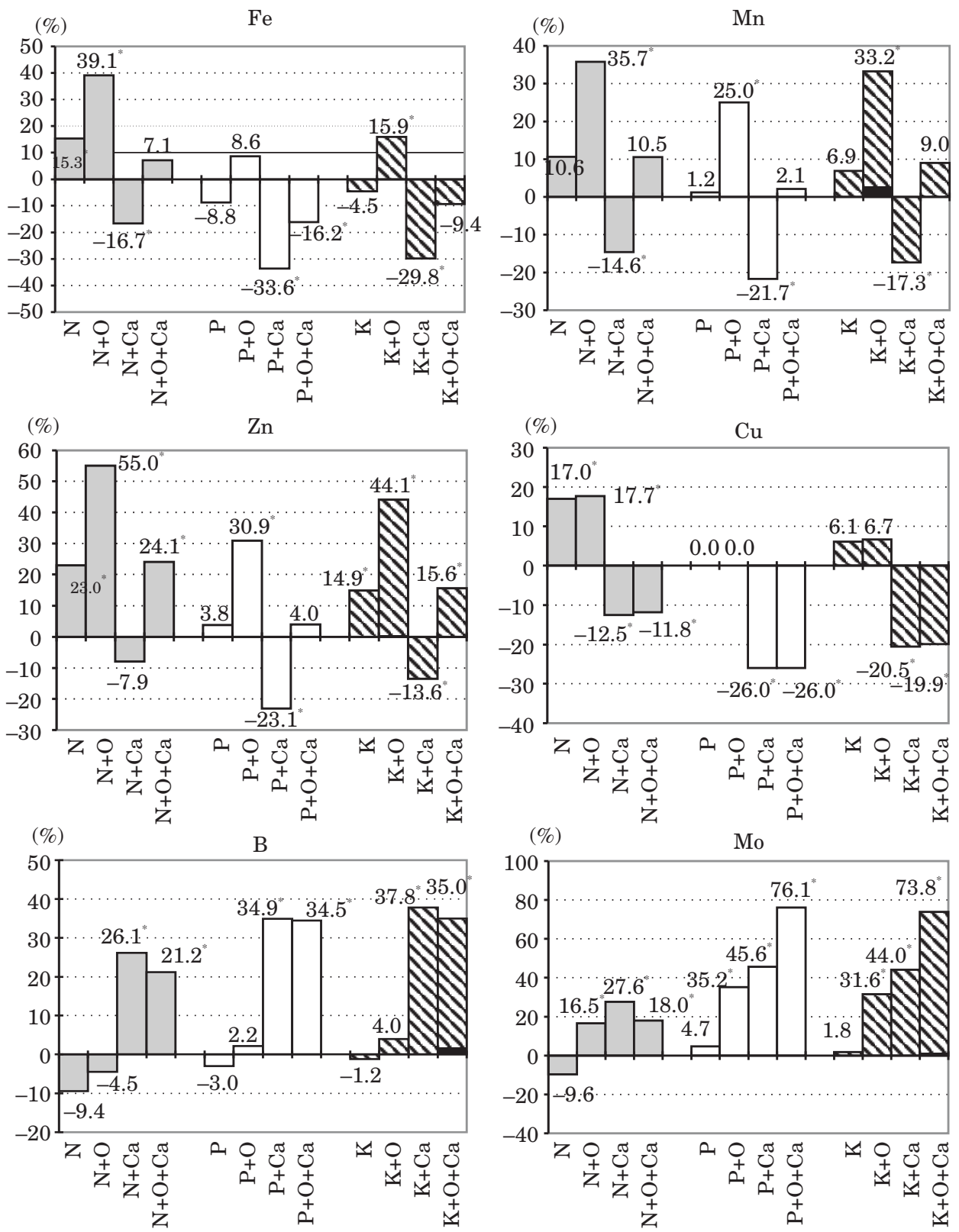

"N - nitrogen fertilization, $\mathrm{P}$ - phosphorus fertilization, $\mathrm{K}$ - potassium fertilization, $\mathrm{Ca}$ - liming, $\mathrm{O}$ - farmyard manure

Fig. 1. Effect of fertilization on changes of $\mathrm{Fe}, \mathrm{Mn}, \mathrm{Zn}, \mathrm{Cu}, \mathrm{B}$ and Mo concentration in soil solution. For the zero level $(0 \%)$ an average was accepted from all fertilizing combinations where a given element was not applied 
obtained by SimARD et al. (1988) indicated the lack of association between the application of decreasing rates of phosphorous and concentrations of manganese and zinc in soil solution. However, Lindsay and STEVEnson (1959a,b) showed that application of $\mathrm{Ca}\left(\mathrm{H}_{2} \mathrm{PO}_{4}\right)_{2}$ onto acidic soils resulted in an increase of solubility of manganese, aluminum and iron when they are around superphosphate granules.

The effect of phosphorous fertilization on the concentration of molybdenum was not indicated in this study (Figure 1), however many authors have reported competition between molybdates and phosphates for location on soil particles in the solid phase (XIE, MCKEnZIE 1991). This competition is caused by similar chemical properties of phosphorous and molybdenum in soil solution. Thus, there exists a theoretical possibility of the use of phosphorous fertilization in order to avoid molybdenum deficiency (SiNGH, KUMAR 1979).

Soil liming significantly decreased the concentration of iron, manganese, zinc and copper as well as it caused an increase of boron and molybdenum in soil solution (Figure 1). The effect of liming on the concentration of microelements in soil solution was initially indicated by a change of soil reaction. Simard et al. (1988) showed that application of $\mathrm{CaCO}_{3}$ resulted in a decrease of the concentration of manganese and zinc in soil solution. These authors suggest that the reason of such changes is binding of these elements by oxides and oxyhydroxides of aluminum and iron as well as sedimentation into less soluble forms. The results of SANDERs (1983) showed minor and irregular decreases in soil solution of the concentration of copper with an increase of $\mathrm{pH}$ due to the fact that copper almost always occurs in soil solution in a chelate form and a rate of formation of these complexes only to a small extent depends on soil solution. An increase of boron concentration in soil solution under soil liming could be caused by an increase of adsorption of this element on soil particles of the solid layer, which reaches the peak for boron at $\mathrm{pH}$ 8-10 (GoldBerg, GLAUBig 1985, 1986). Liming and a resulting increase of soil reaction causes enhancement of molybdenum mobility in soil (RILEY et al. 1987). At higher soil $\mathrm{pH}$ values there is a reduction of the amount of positive charges on soil colloids and an escalation of competition of molybdates and hydroxyl ions for adsorption areas on the particles of solid phase of soil. At the same time, the activity of iron and aluminum oxides able to adsorb molybdenum is decreased, which results in an increase of the concentration of this element in soil solution (REISENAUER et al. 1962, JARELL, DAWSON 1978). The decrease of the concentration of cations (iron, manganese, zinc and copper) observed in soil solution of the samples collected from the fertilization objects treated with lime was associated with an increase of the amount of free negative charges that were bound by cations from soil solution. On the other hand, an increase of the concentration of anions in soil solution that was observed as the effect of liming was associated with sedimentation of insoluble iron and aluminum molybdates 
as well as a decrease of the amount of positive charges on soil particles of the solid layer followed by an increased desorption of anions (boron, molybdenum, into soil solution (SIMARD et al. 1988).

Application of manure always resulted in an increase of the concentration of the investigated elements in soil solution (Figure 1). This was caused by introducing the elements with the mass of organic fertilizer followed by mineralization of the manure organic substance (CURTin, SMillie 1983). An increase of the content of zinc, copper and iron in soil solution after manure application was also observed by Del Castilho et al. (1993). These authors suggest that this phenomenon is due to chemical properties of soil (an increase of electric conductivity of the surface layer of soil, an increase of soil reaction, an increase of the content of easily soluble organic matter).

\section{CONCLUSIONS}

In the experiments discussed in this paper, mineral and natural fertilization was the factor that significantly determined the concentration of microelements in soil:

1. Among mineral fertilizers only nitrogen fertilization caused a decrease of soil $\mathrm{pH}$ and resulted in an increase of the concentration of iron, manganese, zinc and copper in soil solution while the concentration of boron and molybdenum was decreased. Fertilization with phosphorous and potassium did not significantly influence the concentration of microelements in soil solution.

2. Through neutralization of soil reaction, liming caused a decrease of the concentration of iron, manganese, zinc and copper in soil solution while the concentration of boron and molybdenum was increased.

3. A significant increase of the concentration of all investigated elements was observed in soil solution when manure was applied onto soil.

\section{REFERENCES}

Adams M.L., Davis M.R., Powell K. 2001. Effects of grassland afforestation on exchangeable soil and soil solution. Aust. J. Soil Res., 39: 1003-1014.

BADORA A. 2002. Wptyw pH na mobilność pierwiastków $w$ glebach [Effect of pH on mobility of elements in soil]. Zesz Probl. Post Nauk Rol., 482: 21-36.

Campbell D. J., Kinniburgh D. G., Beckett P. H. 1989. The soil solution chemistry of some Oxfordshire soils: temporal and spatial variability. J. Soil Sci., 40: 321-339.

Curtin D., Smillie G. W. 1983. Soil solution composition as affected by liming and incubation. Soil Sci. Soc. Am. J., 47: 701-707.

Del Castilho P., Chardon W. J., Salomons W. 1993. Influence of cattle - manure slurry application on the solubility of cadmium, copper and zinc in a manured acidic, loamy-sand soil. J. Envir. Qual., 22: 689-697. 
Gє̨вSKI M. 1998. Czynniki glebowe oraz nawozowe wptywajace na przyswajalność metali ciężkich przez rośliny [Soil and fertilization factros affecting plant availability of heavy metals]. Post. Nauk Rol., 5: 3-16.

Goldberg S., Glaubig R. A. 1985. Boron adsorption on aluminium and iron oxide minerals. Soil Sci. Soc. Am. J., 49: 1374-1379.

Goldberg S., Glaubig R. A. 1986. Boron adsorption and silicon release by the clay minerals: Kaolinite, montmorillonite and illite. Soil Sci. Soc. Am. J., 50: 1320-1326.

Gorlach E., Gambuś F. 2000. Potencjalnie toksyczne pierwiastki śladowe w glebach (nadmiar, szkodliwość $i$ przeciwdziatanie) [Potentially toxic trace elements in soil excess, harmfulness and prevention)] Zesz. Probl. Post. Nauk Rol., 472: 275-296.

Hoagland D. R., Martin J. C., Stewart G. R. 1920. Relation of the soil solution to the soil extract. J. Agric. Res., 20: 381-395.

Jarrell W. M., Dawson D. M. 1978. Sorption and availability of molybdenum in soils of Western Oregon. Soil Sci. Soc. Am. J., 42: 412-415.

ŁABĘTOwICZ J. 1995. Skład chemiczny roztworu glebowego w zróżnicowanych warunkach glebowych $i$ nawozowych [Chemical composition of soil solution under different soil and fertilization conditions]. SGGW Warszawa, Praca Habil., 103 ss.

Lindsay W. L., Stephenson H. A. 1959a. Nature of the reactions of monocalcium phosphate monohydrate in soils. I. The solution that reacts with the soil. Soil Sci. Soc. Am. Proc., 23: $12-18$.

Lindsay W. L., Stephenson H. A. 1959b. Nature of the reactions of monocalcium phosphate monohydrate in soils. II. Dissolution and precipitation reactions involving iron, aluminium, manganese and calcium. Soil Sci. Soc. Am. Proc., 23: 18-21.

McBride M. B., BlasiaK J. J. 1979. Zinc and copper solubility as a function of pH in acid soil. Soil Sc. Soc. Am. J., 43: 866-870.

PoręBSKa G. 2003. Przydatność sktadu chemicznego roztworów glebowych do oceny jakości gleb leśnych [Applicability, of soil solution chemical composition to evaluation of quality of forest soils]. Wyd. IOŚ, Warszawa, Rozpr. Habil., 126 ss.

Reseinauer H. M., Tabikh A. A., Stont P. R. 1962. Molybdenum reactions with soils and the hydrous oxides of iron, aluminium and titanum. Soil Sci. Soc. Am. Proc., 26: 23-27.

Riley M. M., Robson A. D., Gartrell J. W., R. C. Jeffrey 1987. The absence of leaching of molybdenum in acid soils from Western Australia. Austr. J. Soil Res., 25: 179-184.

SANDERS J. R. 1982. The effect of $p H$ upon the copper and cupric ion concentrations in soil solutions. J. Soil Sci., 33: 679-689.

SANDERS J. R. 1983. The effect of $\mathrm{pH}$ on the total and free ionic concentrations of manganese, zinc and cobalt in soil solution. J. Soil Sci., 34: 315-323.

Simard R. R, Evans L. J., Bates T. E. 1988. The effects of additions of $\mathrm{CaCO}_{3}$ and $\mathrm{P}$ on the soil solution chemistry of a Podzolic soil. Can. J. Soil Sci., 68: 41-52.

Singh M., Kumar V. 1979. Sulphur, phosphorus and molybdenum interactions on the concentration and uptake of molybdenum in soybean plants. Soil Sci., 127: 307-312.

Smal H. 1999. Wtaściwości chemiczne roztworów glebowych gleb lekkich i ich zmiany pod wptywem zakwaszenia [Chemical properties of soil solutions of light soils and their modifications under the influence of acidification]. Rozpr. Nauk. AR. Lublin, 230: 108 ss.

ŚwięCICKI C. W. 1964. Bor $w$ typowych glebach naturalnych Polski [Boron in typical natural soils in Poland]. Rocz. Nauk Rol., 111: 1-15.

Wolt J. D. 1994. Soil solution chemistry - applications to environmental science and agriculture. New York: John Wiley \& Sons, Inc.: 337 ss

XIE R. J., MACKenzie A. F. 1991. Molybdate sorption - desorption in soils treated with phosphate. Geoderma, 48: 321-333. 
